\title{
High Carbohydrate Diet in the Treatment of Diabetes Mellitus
}

\author{
J.C. Patel, A.B. Metha, M.K. Dhirawani, V.J. Juthant, and L. Aiyer \\ Diabetic Clinic, King Edward Memorial Hospital, Pavel, Bombay - 12
}

Received: April 5, 1968

\begin{abstract}
Summary. Restriction of carbohydrate in the diet of diabetics is widely advocated and practised in the Western Countries, but poses a special problem in the treatment of vegetarian diabetic patients in India, since cereals like wheat and rice constitute the major bulk of their diet. Drastic changes in the diet may be needed to curtail carbohydrate intake. 25 adult-onset diabetic patients were therefore allowed to eat their customary diet, and the control of their diabetes was studied. Restrictions were made only in the total caloric intake, where needed, by curtailing fats. The average carbohydrato consumption was $342 \mathrm{~g}$, constituting $67 \%$ of the average total caloric intake. Prompt and adequate clinical and biochemical control of diabetes could be achieved by a moderate dose of oral hypoglycaemic agents or insulin, and maintained during their followup period of 6 months to 8 years without any difficulty despite their high carbohydrate intake. Avantages of such a diet are enumerated.
\end{abstract}

Alimentation riche en hydrates de carbone au cours du traitement du diabète sucré

Résumé. La restriction des hydrates de carbone dans le régime des diabétiques est largement recommandée et pratiquée dans les pays occidentaux, mais pose un problème particulier dans le traitement des diabétiques végétariens en Inde, car les céréales telles que le blé et le riz constituent la majeure partie de leur régime. Des changements énergiques dans le régime peuvent être nécessaires pour diminuer la prise d'hydrates de carbone. 25 diabétiques adultes ont donc été autorisés à suivre leur régime habituel, et l'équilibre de leur diabéte a été étudié. Les restrictions étaient faites seulement dans l'apport calorique total, quand cela était nécessaire, par réduction des matières grasses. La consommation moyenne d'hytrates de carbone était de $342 \mathrm{~g}$, constituant $67 \%$ de l'apport calorique total moyen. Un bon contrôle clinique et biochimique du diabèto pouvait êtro réalisé par l'administration d'une dose modérée d'agents hypoglycémiants oraux ou d'insuline, et maintenu sans difficulté pendant la période d'observation allant de 6 mois à 8 ans, malgré l'apport élevé d'hydrates de carbone. Les avantages d'un tel régime sont énumérés. \section{mellitus}

Kohlenhydratreiche Diät in der Behandlung des Diabetes

Zusammenfassung. Die Einschränkung der Kohlenhydrate in der Diät des Diabetikers wird in den Ländern des Westens viel empfohlen und geübt; sie bietet aber bei der Behandlung von diabetischen Vegetariern in Indien spezielle Probleme, da bei ihnen Getreideprodukte wie Weizen und Reis den überwiegenden Teil der Diät ausmachen. Eine Einschränkung der Kohlenhydratzufuhr würde daher bei diesen Patienten auf eine ausgesprochen drastische Umstellung der Diät hinauslaufen. Bei 25 Diabetikern vom Erwachsenen-Typ wurde daher die Einstellung des Diabetes kontrolliert, während sie ihre gewohnte Kost beibehielten. Soweit eine Kalorieneinschränkung erforderlich war, erfolgte sie durch Verringerung der Fettzufuhr. Der durchschnittliche Kohlenhydratverbrauch belief sich dabei auf 342 g, d.h. $70 \%$ der mittleren Kalorienaufnahme/Tag. Trotz der hohen KH-Zufuhr ließ sich bei diesen Patienten ohne Schwierigkeiten mit mittleren Dosen von oralen Antidiabetika oder Insulin eine gute Diabetes-Einstellung während der Untersuchungsperiode, die sich über $1 / 2-8$ Jahre ausdehnte, erzielen. Die Vorteile einer derartigen Diät werden aufgeführt.

Key-words: High carbohydrate diet, adult-onset diabetes, control of diabetes.

\section{Introduction}

Several published reports recommend that, on an average, carbohydrate should not constitute more than 40 to $50 \%$ of total caloric intake in the diet of diabetios $[1,3,6,8,10]$. Consumption of more than 200 to $250 \mathrm{~g}$ of carbohydrate per day is not desirable, and may make the control of diabetes difficult [1]; besides, it may increase the insulin requirement, and with it the possible frequent occurrence of hypoglycaemic reactions [1].

To restrict carbohydrate intake to $40 \%$ of total caloric intake is not difficult in non-vegetarians. Doughday [3] mentions that carbohydrate constitutes about 45 to $50 \%$ of total caloric intake in the diet of most Americans. However, vegetarian Indians consume a diet in which carbohydrate constitutes 65 to $75 \%$ of their total caloric intake, since cereals like rice, wheat and dal constitute their staple food. Both rice and wheat are very rich in carbohydrate, and restriction of carbohydrate intake cannot be made without restricting them. Such drastic changes in the diet are unlikely to be adhered to over a long period. Having faced such a problem many times, we decided to study the control of diabetes in 25 patients on a high carbohydrate diet. Attention was mainly focussed on whether adequate biochemical control is possible despite a high earbohydrate diet, and whether the requirement for insulin or a hypoglycaemic agent goes up unduly high.

\section{Material and Method}

25 adult-onset diabetic patients attending the Diabetic Clinic of the King Edward Memorial Hospital were taken for the study. There were 15 males and 10 females. Duration of their diabetes varied from one to $71 / 2$ years. Their ages varied from 37 to 73 years with a mean of 50 years, as shown in Table 2 . 
Each patient underwent detailed physical examination, ophthalmoscopic examination, fluoroscopic examination of the chest, urine analysis and a glucose tolerance test at the time of his first attendance, and every three months during follow-up with treatment, so as to judge the biochemical control of diabetes.

Each patient was advised to divide his total daily

Table 1. Composition of typical vegetarian diet

\begin{tabular}{|c|c|c|c|c|c|}
\hline & quantity & $\begin{array}{l}\text { protein } \\
\text { in } \\
g\end{array}$ & $\begin{array}{l}\text { carbo- } \\
\text { hydrate } \\
\text { in } \\
g\end{array}$ & $\begin{array}{l}\text { fats } \\
\text { in } \\
g\end{array}$ & calories \\
\hline Milk & $300 \mathrm{ml}$ & 12.9 & 15.3 & 9.0 & \\
\hline $\begin{array}{l}\text { Atta } \\
\text { (Wheat flour) }\end{array}$ & $200 \mathrm{~g}$ & 24.2 & 138.8 & 3.4 & \\
\hline Rice & $200 \mathrm{~g}$ & 13.6 & 156.4 & 1.0 & \\
\hline Dal & $20 \mathrm{~g}$ & 4.6 & 11.6 & 0.3 & \\
\hline $\begin{array}{l}\text { Vegetables } \\
\text { (mixed) }\end{array}$ & $50 \mathrm{~g}$ & 1.2 & 3.6 & 0.1 & \\
\hline Butter-Milk & $180 \mathrm{ml}$ & 1.4 & 0.9 & 1.8 & \\
\hline Banana & One & 0.6 & 13.3 & 0.6 & \\
\hline $\begin{array}{l}\text { Fats } \\
\text { (for cooking) }\end{array}$ & $60 \mathrm{~g}$ & & & 60.0 & \\
\hline Total & & 58.5 & 339.9 & 76.2 & 2279 \\
\hline
\end{tabular}

intake into three meals, namely breakfast, lunch and dinner. All of them were instructed to avoid concentrated sugars in order to avoid wide fluctuations in the blood sugar level. No changes were made in their routine menu at all. The isocaloric exchanges were freely permitted, as desired; they too involved cereals. The calculations of their dietetic intake were made by detailed interrogation by one of us. The patients were asked to weigh the raw materials of their daily rations, and the $24 \mathrm{~h}$ intake of fat, protein and carbohydrate and total calories was calculated as accurately as possible. Subsequently, patients were instructed to consume the same ration daily. A typical diet is shown in Table 1.

An attempt was made to keep the glucose tolerance and post-prandial blood sugar levels as near to the normal limits as possible, by using adequate doses of oral hypoglycaemic agents. No changes in their diet were made even when control was difficult. We prefered to raise the dose of hypoglycaemic agents instead, to establish adequate biochemical control. However, in order to avoid excessive weight gain, quantitative restriction was advised without any qualitative change in the diet, in some of the patients.

Table 2. Duration of Diabetes, Age, Sex, Weight before and after Therapy, Diet and Treatment

\begin{tabular}{|c|c|c|c|c|c|c|c|c|c|c|c|}
\hline \multirow{2}{*}{$\begin{array}{l}\text { Serial } \\
\text { No. }\end{array}$} & \multirow{2}{*}{$\begin{array}{l}\text { Duration } \\
\text { of Diabetes } \\
\text { in years }\end{array}$} & \multirow{2}{*}{ Age } & \multirow[t]{2}{*}{ Sex } & \multirow{2}{*}{$\begin{array}{l}\text { Wt. } \\
\text { before } \\
\text { therapy } \\
\text { in } \mathrm{kg}\end{array}$} & \multirow{2}{*}{$\begin{array}{l}\text { Wt. at } \\
\text { present } \\
\text { in kg }\end{array}$} & \multicolumn{4}{|c|}{ Diet } & \multirow{2}{*}{$\begin{array}{l}\text { Percentage } \\
\text { calories } \\
\text { from } \mathrm{CHO} \\
\text { sources }\end{array}$} & \multirow{2}{*}{$\begin{array}{l}\text { Treatment } \\
\text { daily maintainance dose }\end{array}$} \\
\hline & & & & & & $\begin{array}{l}\text { CHO } \\
\text { (in } g / c\end{array}$ & $\begin{array}{l}\text { Protein } \\
\text { lay) }\end{array}$ & Fats & Calories & & \\
\hline 1. & 2 & 60 & $\mathrm{~F}$ & 54.3 & 50.8 & 253 & 47 & 41 & 1569 & $64 \%$ & Carbutamide $1 \mathrm{~g}$ \\
\hline 2. & 4 & 43 & $\mathrm{~F}$ & 66.2 & 64.4 & 386 & 57 & 49 & 2213 & $69 \%$ & Tolbutamide $1 \mathrm{~g}$ \\
\hline 3. & 3 & 60 & $\mathrm{~F}^{2}$ & 56.7 & 59.4 & 288 & 61 & 44 & 1792 & $64 \%$ & $\begin{array}{l}\text { Carbutamide } 1 \mathrm{~g}+ \\
\text { Biguanide } 25 \mathrm{mg}\end{array}$ \\
\hline 4. & 2 & 45 & $\mathrm{~F}$ & 51.7 & 52.1 & 395 & 68 & 45 & 2257 & $70 \%$ & Carbutamide $1 \mathrm{~g}$ \\
\hline 5. & 2 & 46 & $\mathrm{~F}$ & 62.1 & 59.9 & 327 & 51 & 59 & 2143 & $65 \%$ & $\begin{array}{l}\text { Carbutamide } 1.5 \mathrm{~g} \\
+ \text { Biguanide } 100 \mathrm{mg}\end{array}$ \\
\hline 6. & 5 & 46 & $\mathbf{M}$ & 64.4 & 64.4 & 450 & 86 & 68 & 2756 & $65 \%$ & Carbutamide $0.75 \mathrm{~g}$ \\
\hline 7. & 5 & 45 & $\mathbf{F}$ & 68.0 & 64.9 & 312 & 53 & 53 & 1937 & $64 \%$ & $\begin{array}{l}\text { Carbutamide } 1 \mathrm{~g}+ \\
\text { Biguanide } 75 \mathrm{mg}\end{array}$ \\
\hline 8. & $31 / 2$ & 58 & $\mathbf{F}$ & 56.7 & 57.1 & 306 & 53 & 55 & 1933 & $63 \%$ & $\begin{array}{l}\text { Tolbutamide } 1 \mathrm{~g}+ \\
\text { Biguanide } 75 \mathrm{mg}\end{array}$ \\
\hline 9. & 3 & 54 & M & 57.1 & 59.4 & 374 & 77 & 59 & 2335 & $64 \%$ & Tolbutamide $1 \mathrm{~g}$ \\
\hline 10. & $71 / 2$ & 52 & $\mathrm{E}$ & 61.7 & 60.3 & 328 & 53 & 60 & 2064 & $63 \%$ & $\begin{array}{l}\text { Chlorpropamide } 500 \mathrm{mg} \\
+ \text { Biguanide } 75 \mathrm{mg}\end{array}$ \\
\hline 11. & 6 & 40 & M & 78.5 & 77.1 & 345 & 55 & 52 & 2095 & $67 \%$ & Tolbutamide $1 \mathrm{~g}$ \\
\hline 12. & $21 / 2$ & 42 & M & 39.0 & 41.7 & 382 & 75 & 68 & 2440 & $62 \%$ & Tolbutamide $1 \mathrm{~g}$ \\
\hline 13. & $11 / 2$ & 56 & $\mathrm{~F}$ & 65.3 & 63.0 & 328 & 56 & 63 & 2103 & $62 \%$ & $\begin{array}{l}\text { Carbutamide } 1 \mathrm{~g}+ \\
\text { Biguanide } 50 \mathrm{mg}\end{array}$ \\
\hline 14. & $\mathbf{3}$ & 54 & $\mathbf{M}$ & 59.4 & 59.4 & 365 & 59 & 61 & 2245 & $65 \%$ & Chlorpropamide $250 \mathrm{mg}$ \\
\hline 15. & 1 & 42 & $\mathbf{F}$ & 47.2 & 45.8 & 345 & 57 & 56 & 2112 & $65 \%$ & Carbutamide $1 \mathrm{~g}$ \\
\hline 16. & 4 & 54 & M & 51.2 & 50.8 & 342 & 52 & 22 & 1785 & $76 \%$ & Carbutamide $1 \mathrm{~g}$ \\
\hline 17. & 2 & 65 & M & 66.7 & 64.4 & 267 & 44 & 39 & 1600 & $66 \%$ & $\begin{array}{l}\text { Carbutamide } 1 \mathrm{~g} \\
\text { Biguanide } 50 \mathrm{mg}\end{array}$ \\
\hline 18. & $11 / 2$ & 46 & $\mathrm{M}$ & 61.7 & 61.7 & 295 & 47 & 40 & 1618 & $72 \%$ & Tolbutamide $1 \mathrm{~g}$ \\
\hline 19. & & 50 & M & 72.1 & 72.6 & 386 & 75 & 56 & 2355 & $66 \%$ & Tolbutamide $1.5 \mathrm{~g}$ \\
\hline 20. & 3 & 52 & M & 66.7 & 64.4 & 362 & 62 & 44 & 2097 & $69 \%$ & Carbutamide $1.5 \mathrm{~g}$ \\
\hline 21. & 1 & 47 & $\mathbf{M}$ & 53.1 & 55.8 & 547 & 94 & 63 & 3141 & $69 \%$ & $\begin{array}{l}\text { Carbutamide } 0.75 \mathrm{~g}+ \\
\text { Biguanide } 50 \mathrm{mg}\end{array}$ \\
\hline 22. & 4 & 39 & $\mathrm{M}$ & 59.9 & 58.9 & 342 & 65 & 48 & 2071 & $66 \%$ & Tolbutamide $1.5 \mathrm{~g}$ \\
\hline 23. & 7 & 61 & M & 57.1 & 55.8 & 309 & 50 & 37 & 1775 & $69 \%$ & Carbutamide $1 \mathrm{~g}$ \\
\hline 24. & 5 & 37 & $\mathbf{M}$ & 54.9 & 52.6 & 318 & 57 & 26 & 1722 & $76 \%$ & Carbutamide $1 \mathrm{~g}$ \\
\hline 25. & 5 & 73 & $\mathbf{M}$ & 53.1 & 53.1 & 268 & 48 & 34 & 1573 & $74 \%$ & Chlorpropamide $25 \mathrm{mg}$. \\
\hline
\end{tabular}




\section{Results}

As seen in Table 2, total caloric intake varied from 1570 to 3140 per day. Carbohydrate, fat and protein consumption varied from 268 to $547 \mathrm{~g}$, from 22 to $68 \mathrm{~g}$ and from 47 to $94 \mathrm{~g}$ respectively. The average carbohydrate, protein and fat consumptions were $342 \mathrm{~g}, 59 \mathrm{~g}$ and $48 \mathrm{~g}$ respectively. Carbohydrates constituted $62 \%$ of central nervous system, peripheral vascular disorders or albuminurea did not develop during that period in the 25 patients.

\section{Follow-up}

All 25 cases were followed up for a period varying from 6 months to 8 years as shown in Table 4

Table 3. Results of Glucose Tolerance Tests before and after Therapy, and Mean Glucose Tolerance during Follow-up

\begin{tabular}{|c|c|c|c|c|c|c|c|c|c|c|c|c|}
\hline \multirow[b]{2}{*}{ Serial No. } & \multicolumn{4}{|c|}{ Before Treatment } & \multicolumn{4}{|c|}{ After Control } & \multicolumn{4}{|c|}{$\begin{array}{l}\text { Mean G.T.T. During } \\
\text { Follow-up }\end{array}$} \\
\hline & Fasting & $1 \mathrm{~h}$ & $11 / 2 h$ & $2 \mathrm{~h}$ & Fasting & $1 \mathrm{~h}$ & $11 / 2 h$ & $2 \mathrm{~h}$ & Fasting & $1 \mathrm{~h}$ & $11 / 2 \mathrm{~h}$ & $2 \mathrm{~h}$ \\
\hline 1. & 235 & 340 & $\mathbf{3 8 0}$ & 380 & 138 & 215 & 237 & 220 & 126 & 217 & 238 & 238 \\
\hline 2. & 150 & 252 & 240 & 198 & 76 & 157 & 140 & 122 & 124 & 180 & 156 & 120 \\
\hline 3. & 140 & 186 & 220 & 190 & 102 & 126 & 114 & 114 & 90 & 90 & 102 & 126 \\
\hline 4. & 186 & 324 & 324 & 296 & 102 & 174 & 144 & 108 & 108 & 170 & 135 & 132 \\
\hline 5. & 186 & 288 & 306 & 276 & 114 & 198 & 198 & 142 & 90 & 186 & 180 & 102 \\
\hline 6. & 133 & 175 & 189 & 154 & 96 & 144 & 136 & 112 & 84 & 147 & 119 & 117 \\
\hline 7. & 161 & 280 & 273 & 262 & 105 & 224 & 182 & 149 & 102 & 168 & 164 & 114 \\
\hline 8. & 126 & 264 & 288 & 270 & 85 & 214 & 168 & 140 & 90 & 192 & 158 & 140 \\
\hline 9. & 126 & 180 & 198 & 168 & 104 & 176 & 172 & 138 & 100 & 170 & 150 & 140 \\
\hline 10. & 130 & 220 & 280 & 260 & 119 & 175 & 154 & 133 & 84 & 136 & 156 & 125 \\
\hline 11. & 250 & 398 & 365 & 308 & 115 & 170 & 120 & 120 & 95 & 165 & 140 & 120 \\
\hline 12. & 240 & 380 & 365 & 290 & 105 & 168 & 150 & 125 & 102 & 195 & 180 & 140 \\
\hline 13. & 114 & 222 & 262 & 222 & 84 & 132 & 192 & 126 & 102 & 150 & 180 & 156 \\
\hline 14. & 178 & 291 & 281 & 252 & 102 & 180 & 144 & 126 & 114 & 168 & 154 & 144 \\
\hline 15. & 128 & 222 & 258 & 257 & 90 & 150 & 168 & 140 & 84 & 149 & 147 & 127 \\
\hline 16. & 161 & 277 & 292 & 300 & 94 & 135 & 134 & 109 & 102 & 168 & 144 & 140 \\
\hline 17. & 133 & 231 & 259 & 259 & 108 & 198 & 137 & 116 & 114 & 188 & 158 & 130 \\
\hline 18. & 171 & 320 & 298 & 292 & 98 & 140 & 140 & 133 & 120 & 156 & 168 & 130 \\
\hline 19. & 180 & $229^{\circ}$ & 292 & 200 & 126 & 222 & 162 & 114 & 120 & 216 & 168 & 120 \\
\hline 20. & 167 & 288 & 190 & 184 & 118 & 190 & 150 & 110 & 124 & 186 & 148 & 130 \\
\hline 21. & 170 & 252 & 235 & 210 & 86 & 168 & 138 & 114 & 126 & 170 & 152 & 118 \\
\hline 22. & 163 & 284 & 220 & 198 & 88 & 178 & 138 & 120 & 114 & 180 & 158 & 130 \\
\hline 23. & 90 & 240 & 252 & 192 & 72 & 150 & 144 & 102 & 120 & 168 & 148 & 118 \\
\hline 24 . & 130 & 236 & 260 & 220 & 90 & 188 & 168 & 140 & 113 & 188 & 170 & 135 \\
\hline 25. & 168 & 290 & 240 & 240 & 100 & 168 & 128 & 90 & 116 & 200 & 147 & 130 \\
\hline
\end{tabular}

to $76 \%$ of the total caloric intake. On an average, $67 \%$ of the total caloric intake was derived from carbohydrate.

In Table 3 are shown the results of glucose tolerance tests before and after therapy, and during follow up. In all cases adequate clinical and biochemical control of diabetes could be achieved with a moderate dose of oral hypoglycaemic agents. Oral hypogylcaemic agents used were carbutamide, tolbutamide, chlorpropamide and a biguanide derivative, either alone or in combination. The maximum dose of hypoglycaemic agent used in the series was carbutamide $1.5 \mathrm{~g}+$ biguanide $100 \mathrm{mg}$ in $24 \mathrm{~h}$ in one patient, as seen in Table 2. Adequate control could be maintained throughout all the period of treatment. Hypoglycaemic reactions were not encountered, since the drug requirement was not unduly high. Two patients who developed cataract were above 60 years of age, and it is difficult to say whether it was due to diabetes. Early retinopathy was noted in 4 cases. During the follow-up period, varying from six months to seven years, there were no episodes of acidotic coma. The manifestation of complications
Table 4. Duration of follow-up of 25 patients

\begin{tabular}{lc}
\hline Duration of follow-up & Number of cases \\
\hline 6 months -1 year & 1 \\
1 year -3 years & 10 \\
3 years -5 years & 9 \\
5 years -7 years & 3 \\
7 years -10 years & 2 \\
\hline
\end{tabular}

Throughout all this period we encountered no difficulty in adequately controlling their hyperglycaemia. Patients were happy since it had simplified their treatment considerably. The average glucose tolerance test during follow-up is shown in Table 3.

\section{Discussion}

It is interesting to compare the recommended diet at the Mayo Clinic [11] for adult diabetic patients with the diet of the patients in the present series, as shown in Table 5 . 
Table 5. Comparison of recommended diet at the Mayo Olinic for adult diabetic patients with the average diet consumed in the present series

\begin{tabular}{|c|c|c|c|c|c|}
\hline & $\begin{array}{l}\text { Carbo- } \\
\text { hydrate } \\
\text { (g) }\end{array}$ & $\begin{array}{l}\text { Protein } \\
\text { (g) }\end{array}$ & $\begin{array}{l}\text { Fat } \\
\text { (g) }\end{array}$ & $\begin{array}{l}\text { Percent- } \\
\text { age of } \\
\text { calories } \\
\text { from } \\
\text { carbo- } \\
\text { hydrate }\end{array}$ & Calories \\
\hline Mayo Clinic diet & 211 & 107 & 105 & $38 \%$ & 2208 \\
\hline & 342 & 56 & 48 & & 2036 \\
\hline
\end{tabular}

Whereas carbohydrate consumption in our patients was almost one and a half times that recommended at the Mayo Clinic, fat and protein were almost half of it.

At the Mayo Clinic, carbohydrate constituted $38 \%$ of the total caloric intake, whereas on an average our patients derived $67 \%$ of their total calories from carbohydrate. A survey by BeAser [2] of members of the American Diabetes Association indicated that the vast majority of the physicians were treating their patients with restricted diet. Thus restriction of carbohydrates in the diet is widely practised.

The objections to a high carbohydrate diet in the control of diabetes are the requirement of a high dose of insulin, frequent hypoglycaemic reactions associated with the high dose of insulin, and difficult biochemical control. As seen from our results, clinical control of diabetes and control of hyperglycaemia were possible in all the cases. The majority of them could be controlled with oral hypogylcaemic agents, and the insulin requirement, in the few patients where it was used, was moderate and did not fluctuate. Although we have presented here only 25 studied cases, we have experienced no difficulty in maintaining normoglycaemia in the vast majority of our vegetarian patients at our diabetic clinic. Rice is a staple food of South Indian vegetarians, and carbohydrate may constitute for some of them as much as $80 \%$ of their total caloric intake. Even in such patients we have found no difficulty in controlling their hyperglycaemia, despite their high carbohydrate consumption. This has been the experience of several other authors $[5,9]$. EARIEST et al. [5] while experimenting with isocaloric diets of various compositions, found that diets of extreme compositions can be tolerated without clinical complications, at least for a short term. They kept the patients on diets with carbohydrate as high as 71 to $73 \%$ of their total caloric intake, and they found it easier to maintain the blood sugar at the same level as before or even at lower levels. In their series, most of the patients could be controlled with a smaller dose of insulin, especially those who lost considerable weight. Only once did they note hypoglycaemic coma, since contrary to the popular belief, there was no increase in insulin requirement with high carbohydrate intake. As seen in Table 2, none of our patients lost significant weight. As a matter of fact a few gained a little weight.
It is therefore our belief that maintainance of adequate biochemical control despite such high carbohydrate intake, is not due to weight loss.

Forsyth et al. [7] mention that endogenous hyperglycaemia should be differentiated from exogenous hyperglycaemia. Endogenous hyperglycaemia is the result of the breakdown of glycogen storage and tissue proteins, and is an expression of poor carbohydrate utilization. It is usually accompanied by ketosis. Whereas exogenous hyperglycaemia results from abundant carbohydrate intake and is not accompanied by ketosis. The undesirability of endogenous hyperglycaemia is unanimously agreed upon, but that of exogenous hyperglycamia is questionable [7]. Besides, we see no reason in restricting carbohydrate intake when we could control even exogenous hyperglycaemia, and could keep the glucose tolerance reasonably near the normal limits.

In fact, it has been recommended that carbohydrate intake should be kept high in diabetic patients $[5,9]$. Decreased glucose oxidation results in the disturbances of oxidation, synthesis, and mobilization of lipids. The aim in the treatment should be to increase glucose oxidation to a normal rate, and this can be achieved by raising carbohydrate intake. Moreover, there would be decrease in fat content of the diet, which should diminish the tendency to ketoacidosis [5].

We do not recommend a free diet in the sense used by some workers, who allow their patients to eat whatever they choose, except concentrated sugars to prevent wide fluctuations, and give them hypoglycaemic agents in a dose sufficient to control their symptoms $[12,13]$. Some hyperglycaemia and glycosuria was permissible, and in fact unavoidable, with that type of treatment. On the other hand, our therapeutic aim was to maintain the normoglycaemia as effecteively as possible, despite their high carbohydrate diet. The only restriction that we imposed was to keep the calorie intake at a level just sufficient for their requirements, in order to avoid excessive weight gain.

The advantages of such treatments are very dis. tinct. Major changes in the patient's routine diet and imposing rigid restrictions are likely to cause psychological upsets. Since the treatment of diabetes lasts the life time, it may be that the patient may not persevere with the treatment for a long time.

Where carbohydrate is restricted, caloric intake can be made up only from protein and fat. This increases the cost of treatment considerably. The majority of our patients belong to the lower socio-economic group, and hence cannot afford such a treatment. Vegetarians here have very limited sources of proteins, and hence it is very difficult to raise their protein intake. The present study leads us to believe that adult-onset diabetics in our country tolerate carbohydrate very well, and there is no need to restrict the carbohydrate content of their diet, since adequate biochemical control is possible without difficulty. 
Acknowledgement. We are thankful to the Dean, K.E. M. Hospital, Bombay, for allowing us to use the hospital records.

\section{References}

1. Alrar, F.N.: Diabetic treatment of diabetes. Med. Clin. N. Amer. 44, 423-427 (1960).

2. BrasER, S.B.: A survey of present day treatment of diabetes mellitus. New Engl. J. Med. 244, 714 (1951).

3. DodGHDAY, W.H.: Dietary treatment of adults with diabetes mellitus. J. Amer. med. Ass. 167, 859-862 (1958).

4. - Present status of dietary treatment of diabetes. Nutr. Rev. 17, 289-291 (1959).

5. Ernhest, L., E. Linner, and A. Svanborg: Carbohydrate rich fat-poor, diet in diabetes. Amer. J. Med. $39,594-600$ (1965).

6. Forsham, P.H., J. Stemnke, and G.W. Thore: Diabetes Mellitus in Principles of Internal Medicine, p. 495. New York: Megraw Hill Book Company Inc. 1966.

7. Forsyth, C.C., T.W.G. KinneaR, and D.M. DUNLOP: Diet in diabetes. Brit. med. J. 1951 I, 1095 - 1101.
8. Jostrn, E.P., H.F. Root, P. White, and A. MaRbIe: The treatment of diabetes mellitus, 10th Edition, p. 562-576. Philaldephia: Lea \& Febiger 1959.

9. Kemperer, W., R.L. Peschel, and C. Schlayer: Effect of rice diet on diabetes mellitus associated with vascular diseases. Postgrad. Med. 24, 359-371 (1958).

10. Mayo Clinic Diet Manual, p. 96. Philadelphia: W.B. Saunders Co. 1954.

11. Rroketts, H.T., and H.L. WILDBERger: Diagnosis and management of diabetes mellitus in general office practice. Med. Clin. N. Amer. 45, 1505-1513 (1961).

12. Tolstor, E. \& T.P. Almy, and V. ToscAnt: Treatment of diabetes mellitus with protamine insulin. Is a persistent glycosuria harmful ? A metabolic study of a severe case. Ann. intern. Med. 16, 893-903 (1942).

13. - , and F. C. WEBER: Protamine zine insulin: A Metabolic study. Arch. intern. Med. 64, 91-104 (1939).

\author{
Dr. J.C. Pateit \\ Diabetic Clinic \\ K.E.M. Hospital \\ Pavel, Bombay - 12 \\ India
}

